\title{
Fındıktan üretilen atıkların toprağın fiziko-kimyasal ve biyolojik özelliklerine etkileri
}

\section{Effects of hazelnut produced wastes on physico-chemical and biological properties of soil}

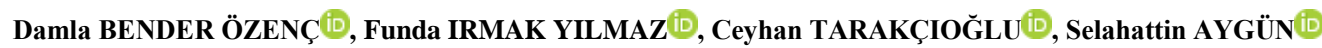 \\ ${ }^{1}$ Ordu Üniversitesi, Ziraat Fakültesi, Toprak Bilimi ve Bitki Besleme Bölümü, 52200, Ordu \\ Sorumlu yazar (Corresponding author): D. Bender Özenç, e-posta (e-mail): damlabender@odu.edu.tr \\ Yazar(lar) e-posta (Author e-mail): fundairmak@ hotmail.com, ctarakcioglu@odu.edu.tr, selahttin_555@ hotmail.com
}

\section{MAKALE BILGISII}

Alınıs tarihi 12 Mart 2019

Düzeltilme tarihi 19 Nisan 2019

Kabul tarihi 26 Nisan 2019

\section{Anahtar Kelimeler:}

Zuruf

Biyokömür

Toprak özellikleri

Besin elementi

\begin{abstract}
ÖZ
Bu çalıșmada, findığın hasat artığı olan zuruf ile findık kabuğundan üretilen biyokömür farkl dozlarda (0-3-6 t da $\left.{ }^{-1}\right)$ toprağa karıştırılmış ve inkübasyona (1-2-3-4 ay) bırakıldıktan sonra toprağın fiziksel, biyolojik ve kimyasal özellikleri üzerine etkileri incelenmiştir. Deneme tesadüf parselleri deneme desenine göre, 3 tekerrürlü olarak sera koşullarında yürütülmüştür. Materyallerin toprağa uygulama dozu arttıkça incelenen tüm özelliklerde (hacim ağırlığı hariç) artış meydana gelmiștir. İnkübasyon süresinin etkisi özelliklere göre değişmiş, doygunluk yüzdesi, havalanma kapasitesi, hidrolik iletkenlik, elektriksel iletkenlik değerleri 4 aylık, kolay alınabilir su yüzdesi ve agregat stabilitesi, 3 aylık inkübasyon süresinde findık zurufu uygulamalarında en yüksek olmuştur. Toprak organik madde miktarı, toplam $\mathrm{N}$ içeriği inkübasyon süresi uzadıkça azalmış, bitkiye yarayışılı fosfor içeriği 3 aylık, ekstrakte edilebiliı potasyum 2 aylık, demir, bakır, mangan ve çinko içerikleri 1 aylık inkübasyon süresinde en yüksek çıkmıştır. Toprak biyolojik özellikleri üzerine $\beta$-glukozidaz enzim aktivitesi dışında, $\mathrm{CO}_{2}$, değeri 1 aylık, mikrobiyal biyomas-C değeri 2 aylık ve aril sülfataz enzim aktivites üzerine 3 aylık inkübasyon döneminde biyokömür uygulamaları etkili olmuştur. Tüm veriler değerlendirildiğinde, incelenen materyallerin toprak özelliklerini iyileştirdiği ve 3 ton da $^{-1}$, uygulamanın yeterli olacağı tespit edilmiş̧ir. Ayrıca, fındık zurufunun kısa süreli etkisinin daha fazla olduğu, biyokömürün daha uzun dönemde etkilerinin incelenmesi gerektiği düşünülmektedir.
\end{abstract}

\section{ARTICLE INFO}

Received 12 March 2019

Received in revised form 19 April 2019 Accepted 26 April 2019

\section{Keywords:}

Husk

Biochar

Soil properties

Nutrient elements

\begin{abstract}
In this study, hazelnut husk and the biochar produced from the hazelnut shell was mixed into the soil at different doses $\left(0-3-6 \mathrm{t} \mathrm{da}^{-1}\right)$ and left to incubation (1-2-3-4 months) and then effects on the physical, biological and chemical properties of the soil were investigated. The experiment was carried out in greenhouse conditions according to the randomized plot design as 3 replications. As the application dose of the materials to soil increased, all properties examined (excluding bulk density) increased. The effect of the incubation period was changed according to the characteristics; saturation percentage, aeration capacity, hydraulic conductivity, electrical conductivity values were 4-monthly, easily available water content and aggregate stability were the highest in 3-monthly incubation time at hazelnut husk applications. The amount of soil organic matter and the total $\mathrm{N}$ content decreased depending on the prolongation of the incubation time; available phosphorus content 3-monthly, extractable potassium 2-monthly, iron, copper, manganese and zinc contents were highest in the 1-month incubation time. Biochar applications were effective on biological properties of soil (except $\beta$-glucosidase enzyme activity); $\mathrm{CO}_{2}$ value was 1-monthly, microbial biomass-C value was 2- monthly and aryl sulfatase enzyme activity was found to be highest in 3-monthly incubation time. When all the data were evaluated, it was determined that the examined materials improved the soil properties and 3 ton $\mathrm{da}^{-1}$ application would be sufficient. In addition, it is thought that the short term effect of hazelnut zuruf is higher and the effects of biochar on the longer term should be examined.
\end{abstract}




\section{Giriş}

Toprakların sürdürülebilir kullanımı için temel toprak özelliklerinin bozulmadan devamlılığın sağlanması temel amaç olmalıdır. Toprakların temel olan fiziksel, kimyasal ve biyolojik özelliklerinin devamlılığının sağlanmasında toprak organik madde kapsamının artırılması ya da organik madde kaynağının devamlılığ toprakların etkinliği ve üretkenliğini artırmada önemli işleve sahip olmasına rağmen, yoğun tarımsal uygulamalar toprak organik madde miktarının azalmasına neden olmaktadır (Grandy ve ark. 2002; Lal 2009). Bu nedenle, tarımsal verimliliğin uzun dönem sürdürülebilirliği için, yeterli kalitede organik atıkların kullanımı (Khai ve ark. 2008; González ve ark. 2010; De Lucia ve Cristiano 2015) toprak organik maddesinin korunmasını sağlayacaktır.

Günümüzde her türlü atığın tekrar topraklara kazandırılması üzerinde durulan önemli bir konu olup, hem toprakların kaybettiği organik madde kaynaklarının karşılanması hem de üretici için sorun teşkil eden hasat artıklarının değerlendirilmesi, pratikte uygulanabilirliği yüksek yollardan biri olmaktadır. Hasat atıkları, kentsel katı veya gıda işleme sanayi atıkları ve hayvan gübresi gibi organik atıklar kompost üretimi için uygundur (Stellacci ve ark. 2013; Rinaldi ve ark. 2014). Bu tür materyaller toprak organik madde miktarı ve besin içeriği üzerine hemen etkili olması yanında, toprakların tamponlama kapasitesini artırmakta, toprak enzim ve solucan aktivitesini zenginleştirmekte, özellikle de fiziksel toprak kalitesini artırmaktadır (Ferreras ve ark. 2006; Cheng ve ark. 2007; Khai ve ark. 2008; De Lucia ve Cristiano. 2015). Zare ve ark. (2010), organik atık uygulamalarının toprak hidrolik iletkenliği ve su tutma kapasitesini artırdığını; makro por devamlılığ sağlanmasına bağlı olarak havalanma ve drenaj gibi olayları belirleyen por büyüklük dağılımını iyileştirdiğini (Alaoui ve ark. 2011) ifade etmişlerdir. Organik atık ve kompost ürünlerinin dışında, son yıllarda atıklardan üretilen biyokömürün toprakta kullanımı ile ilgili araştırmalar hız kazanmıştır. Biyokömür, organik maddelerin oksijensiz ortamda pirolizi yoluyla elde edilen yüksek karbon ve mineral madde içeren (Lehmann 2007), ince taneli, çok gözenekli bir kömür maddesidir. Taze organik materyaller bitkiler ve toprak mikroorganizmalar için besin sağlarken, yüksek yüzey alanlı ve gözenekliliğe sahip biyokömür besin ve suyun bitkiler tarafından alımını artıran bir katalizör görevi yapmakta ve ayrıca yararlı mikroorganizmaların gelişmesine yönelik bir yaşam alanı oluşturmaktadır (Lehmann ve Rondon 2006; Warnock ve ark. 2007). Findık kabuğunun yüksek C'lu bir materyal olması onun biyokömür yapımına uygun olduğunun göstergesidir. Fındık kabuğundan üretilen biyokömürün toprak özelliklerine olası etkileri ilgili çalışmalar oldukça azdır.

Ülkemiz için önemli bir ürün olan fındık, hasat edildiğinde $1 \mathrm{~kg}$ yaş findıktan 1/3'i kuru kabuk, 1/5'i kuru zuruf olarak açığa çıkmaktadır. Yıllara göre ürün verimi ve buna bağlı olarak atık miktarı değişmekle beraber, her yıl ortalama 500000 ton civarında tarımsal atık olarak ortaya çıkmaktadır (Aygün 2015).
Yapılan çalışmalarda, findık zuruf kompostunun bileşiminin çiftlik gübresine yakın ya da daha zengin olduğu (Çalışkan ve ark. 1996), toprakların fiziksel ve kimyasal özelliklerini iyileştirdiği (Zeytin ve Baran 2003; Bender Özenç ve Özenç 2008; Birol ve Bender Özenç 2011; Gülser ve ark. 2015), toprakta mikrobiyal faaliyetleri büyük oranda arttırdığg 1 (Kızılkaya ve ark. 2015), zuruf kompostunun doğal yapısında yer alan organik öğelerin ayrışmaya daha dirençli olduğu ve bitki gelişimini artırdığı (Özenç 2004), toprağın tamponlama kapasitesini artırarak $\mathrm{pH}$, elektriksel iletkenlik, değişebilir katyonların miktarı, organik madde ve toplam azot içeriğini artırdığı (Özenç ve Çalışkan 2001; İslam 2016) bildirilmiştir.

$\mathrm{Bu}$ çalışmanın amacı, findık hasat atığı olan zuruf ile findık kabuğundan üretilen biyokömürün topraklara karıştırılması ile toprakların fiziksel, biyolojik ve kimyasal özellikleri üzerine etkilerini araştırmak ve karşılaş̧ırmaktır.

\section{Materyal ve Yöntem}

\subsection{Materyal}

$\mathrm{Bu}$ çalışmada, Ordu Üniversitesi deneme alanından alınan $(0-20 \mathrm{~cm})$ kumlu tın tekstürlü toprak, organik materyal olarak ise üreticiden temin edilen 4 yıllık findık zurufu (FZ), findık kabuğunun $380^{\circ} \mathrm{C}$ 'de sistemden 4.5 saat yakılmasiyla elde edilen (PAL Havacılık Ziraat San. Tic. Ltd. Şti.) biyokömür (BK) kullanılmıştır. Denemede kullanılan toprak ve organik materyallere ait bazı fiziksel ve kimyasal özellikler Çizelge 1' de verilmiştir.

Deneme toprăğ, hafif alkalin, tuzsuz ve organik madde içeriği az, tuttuğu nem içeriği oldukça düşük, hidrolik iletkenlik değeri bakımından oldukça hızlı geçirgen, suya dayanıklı agregat stabilite yüzdesi düşüktür. Fındık zurufu hafif asit, organik madde içeriği yüksek, havalanma kapasitesi ve kolay alınabilir su içeriği bakımından ideal sınırlar içerisinde olup, biyokömür nötr $\mathrm{pH}$, yüksek organik madde kapsamı ve havalanma kapasitesine sahiptir.

Deneme toprağ1 ve organik materyallerin besin elementi içerikleri: Toprağın toplam N (\%0.096)'u yeteli, yarayışlı P (7.2 $\left.\mathrm{mg} \mathrm{kg}^{-1}\right)$ ve ekstrakte edilebilir Mn (8.07 $\left.\mathrm{mg} \mathrm{kg}^{-1}\right)^{\prime} 1 \mathrm{az}$, ekstrakte edilebilir K (43.6 mg kg-1)'u çok az, Fe (23.41 mg kg-1), Cu (4.36 mg kg-1) ve $\mathrm{Zn} \mathrm{(6.83} \mathrm{mg} \mathrm{kg}^{-1}$ )'u fazla sinıfinda yer almaktadır. Fındık zurufu ve biyokömür materyallerinin N'u \%0.32-0.07, P'u 1045-165 mg kg-1, K'u 29442-7302 mg kg-1, Fe'i 1701-377 mg kg-1, Cu'1 16.3-17.2 mg kg-1, Mn'1 467-66.2 $\mathrm{mg} \mathrm{kg} \mathrm{kg}^{-1}$ ve $\mathrm{Zn}$ konsantrasyonu $51.4-75.9 \mathrm{mg} \mathrm{kg}^{-1}$ olarak belirlenmiştir (Tarakçığlu ve ark. 2019).

\subsection{Denemenin kurulmasl}

Deneme, Ordu Üniversitesi Ziraat Fakültesine ait deneme serasında yürütülmüştür. Deneme kurulmadan önce toprak ve materyaller $4 \mathrm{~mm}$ 'lik elekten elenmiştir. Tesadüf parselleri deneme desenine göre, dört inkübasyon süresi (1-2-3-4 ay), iki farklı organik materyal (findık zurufu, biyokömür), üç

Çizelge 1. Organik materyaller ve toprağın bazı fiziksel ve kimyasal özellikleri.

Table 1. Some physical and chemical properties of organic materials and soil.

\begin{tabular}{cccccccccc}
\hline & HA $\left(\mathrm{g} \mathrm{cm}^{-3}\right)$ & Saturasyon $(\%)$ & HK $(\%)$ & KAS $(\%)$ & HI $\left(\mathrm{cm} \mathrm{h}^{-1}\right)$ & AS $(\%)$ & OM $(\%)$ & $\mathrm{pH}(1: 3)$ & EC $\left.(\mu \mathrm{S} \mathrm{m})^{-1}\right)$ \\
\hline Toprak & 1.32 & 52.21 & 7.00 & 6.96 & 7.57 & 13.2 & 1.08 & 8.14 & 313 \\
Findik Zurufu & 0.17 & 74.98 & 26.24 & 17.23 & - & - & 64.87 & 6.51 \\
Biyokömür & 0.36 & 48.93 & 34.06 & 4.64 & - & - & 98.04 & 6.95 \\
\hline
\end{tabular}

HA: Hacim ağırlı̆̆, HK: Havalanma kapasitesi, KAS: Kolay alınabilir su içeriği, Hİ: Hidrolik iletkenlik, AS: Agregat stabilitesi, OM: Organik madde, EC: Elektriksel iletkenlik. 
uygulama dozu (0-3-6 t da $\left.{ }^{-1}\right)$ ve üç tekrarlamalı olarak kurulmuştur. Denemede, hava kuru $3 \mathrm{~kg}$ toprak alan saksılar kullanılmıştır. Uygulama oranlarına göre toprağa karıştırılacak materyal miktarı hesapladıktan sonra bir kap içerisinde toprakla iyice karıştırılıp, saksılara doldurulmuş ve nemlendirilmiş, inkübasyon süreleri boyunca saksıların nem kontrolü takip edilerek tamamlanmıştır.

\subsection{Yöntem}

Toprakta tekstür analizi hidrometre yöntemi (Bouyoucos 1951)'a, agregat stabilitesi Demiralay (1993)'a, hidrolik iletkenlik Sönmez (1960)'e göre yapılmıştır. Biyokimyasal özelliklerden toprak solunumu İsermeyer (1952), mikrobiyal biyomas-C Anderson (1982), $\beta$ - glukozidaz enzim aktivitesi Eivazi ve Tabatabai (1988)'a göre, aril sülfataz enzim aktivitesi Tabatabai ve Bremner (1970) tarafindan kullanılan yöntemlerle belirlenmiştir. pH ve EC 1:2.5 oranındaki toprak:su karışımda, organik madde Walkley-Black 1slak yakma yöntemiyle, toplam azot Kjeldahl yaş yakma yöntemiyle, bitkiye yarayışlı fosfor, ekstrakte edilebilir potasyum nötr $1 \mathrm{~N} \mathrm{NH}_{4} \mathrm{CH}_{3} \mathrm{COO}$ çözeltisi ile, ekstrakte edilebilir $\mathrm{Fe}, \mathrm{Zn}, \mathrm{Cu}, \mathrm{Mn}$ ise DPTA ile atomik absorpsiyon cihazında Kacar (2009) tarafindan belirtilen yöntemlerle yapılmıştır.

Organik materyallerin hacim ağırlığ (1986)'a, saturasyon, havalanma kapasitesi ve kolay alınabilir su içeriği De Boodt ve ark. (1973)'na, pH ve EC 1:3 oranındaki organik materyal-saf su karışımında, organik madde $550 \pm 25^{\circ} \mathrm{C}$ ' de 4 saat süreyle yakılması ile Kacar (2009)'a göre; bitki besin elementi analizleri ise Kacar ve Kütük (2010) tarafından belirtilen yöntemlerle yapılmıştır.

Deneme sonunda elde edilen verilerin JUMP paket programı kullanılarak varyans analizleri yapılmış ve uygulamalar arasındaki farklılıklar için $\% 1$ ve $\% 5$ önem düzeyinde Tukey çoklu karşılaştırma testine göre değerlendirilmiştir.

\section{Bulgular}

\subsection{Toprak fiziksel ve kimyasal özellikleri}

Toprak düzenleyicisi olarak kullanılan findık zurufu ve biyokömürün toprağın fiziksel ve kimyasal özelliklerine ilişkin veriler Çizelge 2'de sunulmuştur. Veriler incelendiğinde, toprak pH'sı haricinde tüm özelliklerde zuruf materyalinin daha etkili olduğu, uygulama dozu arttıkça, toprak hacim ağırlı̆ğ dışında diğer özelliklerinde artış meydana geldiği görülmüştür. Toprağın suya dayanıklı agregat yüzdesi 2 aylık inkübasyon süresinde artmış, sonra azalma eğilimi gösterirken, hidrolik iletkenlik 4 aylık dönemde en yüksek çıkmıştır. Diğer yandan, toprağın hacim ağırlığı, havalanma kapasitesi ve kolay alınabilir su içeriği üzerine inkübasyon süresi ile uygulama dozları arasındaki etkileşim istatistiksel olarak önemli farklılıklar $(\mathrm{p}<0.01)$ meydana getirmiştir. Organik atık karıştırılmamış toprağın 1 aylık inkübasyon süresinde hacim ağırlığı 1.29 $\mathrm{g} \mathrm{cm}^{-3}$, toprak havalanma kapasitesi 3 ve $6 \mathrm{t} \mathrm{da}^{-1}$ materyal uygulanan 4 aylı inkübasyon döneminde \%17.8-19.1, kolay alınabilir su içeriği 3 aylık inkübasyon döneminde toprağa $6 \mathrm{t}$ $\mathrm{da}^{-1}$ materyal uygulamasında $(\% 11.8)$ en yüksek çıkmıştır. Ayrıca, organik materyal ve uygulama dozlarının etkileşimi toprak havalanma kapasitesi $(\mathrm{p}<0.05)$, organik madde, $\mathrm{pH}$ ve elektriksel iletkenlik değerlerinde $(\mathrm{p}<0.01)$ farklılıklar meydana getirmiştir. Havalanma kapasitesi, organik madde ve EC değerlerinde findık zurufunun, $\mathrm{pH}$ üzerine ise biyokömürün 6 $\mathrm{t} \mathrm{da}^{-1}$ uygulamasının en etkili doz olduğu belirlenmiştir.

\subsection{Toprağın biyolojik özelliklerine etkisi}

Toprağa farklı dozlarda uygulanan findık zurufu ve biyokömür materyallerinin inkübasyon süresine bağlı olarak toprağın biyolojik özelliklerine ait veriler Çizelge 3 'de verilmiştir. Çizelgeden de görüleceği üzere, incelenen biyolojik özelliklerde biyokömür uygulaması, $\beta$-glukozidaz enziminde ise fındık zurufu daha etkili olmuştur. Toprağın $\mathrm{CO}_{2}$ miktarı 1

Çizelge 2. Organik materyal, inkübasyon süresi ve uygulama dozlarının toprağın bazı fiziksel ve kimyasal özelliklerine etkisi.

Table 2. Effects of organic material, incubation time and application doses on some physical and chemical properties of soil.

\begin{tabular}{|c|c|c|c|c|c|c|c|c|}
\hline & $\mathrm{HA}\left(\mathrm{g} \mathrm{cm}^{-3}\right)$ & HK $(\%)$ & KAS (\%) & $\mathrm{HI}\left(\mathrm{cm} \mathrm{h}^{-1}\right)$ & AS (\%) & $\mathrm{OM}(\%)$ & $\mathrm{pH}(1: 2.5)$ & $\mathrm{EC}(1: 2.5)$ \\
\hline \multicolumn{9}{|c|}{ Organik Materyal (OM) } \\
\hline Zuruf & 1.06 & $12.17^{\mathrm{a}}$ & 7.72 & $12.11^{\mathrm{a}}$ & $22.46^{\mathrm{a}}$ & $1.05^{\mathrm{a}}$ & $7.96^{\mathrm{b}}$ & $491^{a}$ \\
\hline \multirow[t]{2}{*}{ Biyokömür } & 1.07 & $10.98^{b}$ & 8.08 & $11.22^{b}$ & $20.02^{b}$ & $0.89^{\mathrm{b}}$ & $8.08^{\mathrm{a}}$ & $340^{\mathrm{b}}$ \\
\hline & öd & ** & öd & * & *** & ** & ** & ** \\
\hline \multicolumn{9}{|c|}{ İnkübasyon Süresi (İS, ay) } \\
\hline 30 & $1.15^{\mathrm{a}}$ & $9.36^{\mathrm{c}}$ & $7.16^{\mathrm{bc}}$ & $9.02^{\mathrm{c}}$ & $20.52^{b}$ & $1.07^{\mathrm{a}}$ & $7.96^{\mathrm{b}}$ & $374^{c}$ \\
\hline 60 & $1.09^{\mathrm{b}}$ & $10.12^{\mathrm{c}}$ & $8.11^{\mathrm{b}}$ & $10.73^{b}$ & $26.05^{\mathrm{a}}$ & $0.99^{\mathrm{ab}}$ & $7.99^{\mathrm{b}}$ & 399 bc \\
\hline 90 & $1.03^{\mathrm{c}}$ & $11.75^{\mathrm{b}}$ & $9.74^{\mathrm{a}}$ & $12.03^{\mathrm{b}}$ & $22.23^{\mathrm{b}}$ & $0.95^{\mathrm{ab}}$ & $8.02^{b}$ & $427^{\mathrm{ab}}$ \\
\hline \multirow[t]{2}{*}{120} & $0.96^{\mathrm{d}}$ & $14.92^{\mathrm{a}}$ & $6.60^{\mathrm{c}}$ & $14.87^{\text {a }}$ & $16.15^{\mathrm{c}}$ & $0.89^{\mathrm{b}}$ & $8.11^{\mathrm{a}}$ & $460^{\mathrm{a}}$ \\
\hline & ** & ** & *** & ** & ** & ** & ** & $* *$ \\
\hline \multicolumn{9}{|l|}{$\operatorname{Doz}\left(\mathrm{D}, \mathrm{t} \mathrm{da}^{-1}\right)$} \\
\hline 0 & $1.17^{\mathrm{a}}$ & $7.00^{\mathrm{b}}$ & $6.97^{\mathrm{b}}$ & $10.31^{\mathrm{b}}$ & 21.33 & $0.86^{\mathrm{b}}$ & 8.02 & $322^{\mathrm{c}}$ \\
\hline 3 & $1.02^{\mathrm{b}}$ & $13.48^{\mathrm{a}}$ & $8.05^{\mathrm{a}}$ & $12.06^{\mathrm{a}}$ & 20.26 & $0.99^{\text {a }}$ & 8.03 & $431^{b}$ \\
\hline \multirow[t]{2}{*}{6} & $0.99^{b}$ & $14.24^{\mathrm{a}}$ & $8.69^{\mathrm{a}}$ & $12.61^{\mathrm{a}}$ & 22.12 & $1.07^{\mathrm{a}}$ & 8.00 & $492^{a}$ \\
\hline & $* *$ & $* *$ & $* *$ & $* *$ & öd & $* *$ & öd & $* *$ \\
\hline \multirow[t]{4}{*}{ İSxOM } & öd & öd & öd & öd & öd & öd & öd & öd \\
\hline & $* *$ & $* *$ & $* *$ & öd & öd & öd & öd & öd \\
\hline & öd & $*$ & öd & öd & öd & $* *$ & $* *$ & $* *$ \\
\hline & öd & öd & öd & öd & öd & öd & öd & öd \\
\hline
\end{tabular}

*, **: İstatiksel olarak $\mathrm{P}<0.05$ ve $\mathrm{P}<0.01$ düzeyinde önemli, öd: İstatistiksel olarak önemli değil. Özellikler için yapılan varyans analizi sonucunda en az iki grup ortalaması arasındaki fark istatistiksel olarak önemli bulunmuştur. Aynı harfle gösterilen ortalamalar arasındaki fark, kendi grubu içerisinde önemli değildir. 
Çizelge 3. Organik materyal, inkübasyon dönemi ve doz etkileşiminin toprak biyolojik özelliklerine etkisi.

Table 3. Effect of organic materials, incubation period and dose interaction on some biological properties of soil.

\begin{tabular}{|c|c|c|c|c|c|c|c|c|c|c|}
\hline \multirow{3}{*}{\multicolumn{2}{|c|}{$\operatorname{Doz}\left(\mathrm{D}, \mathrm{t} \mathrm{da}^{-1}\right)$}} & \multicolumn{8}{|c|}{ İnkübasyon Süresi } & \multirow{3}{*}{ Ort. (D) } \\
\hline & & \multicolumn{2}{|c|}{$1 . \mathrm{AY}$} & \multicolumn{2}{|c|}{$2 . \mathrm{AY}$} & \multicolumn{2}{|c|}{ 3.AY } & \multicolumn{2}{|c|}{$4 . \mathrm{AY}$} & \\
\hline & & FZ & $\mathrm{BK}$ & FZ & BK & FZ & BK & FZ & $\mathrm{BK}$ & \\
\hline \multirow{3}{*}{$\begin{array}{c}\mathrm{CO}_{2} \\
\left(\mathrm{mg} 100 \mathrm{~g}^{-1} \text { gün }^{-1}\right)\end{array}$} & 0 & \multicolumn{2}{|c|}{$0.12^{f * *}$} & \multicolumn{2}{|c|}{$0.15^{\mathrm{ef}}$} & \multicolumn{2}{|c|}{$0.29^{\mathrm{cf}}$} & \multicolumn{2}{|c|}{$0.25^{\mathrm{cf}}$} & $0.21 \mathrm{~b}$ \\
\hline & 3 & $0.36^{\mathrm{be}}$ & $0.64^{\mathrm{a}}$ & $0.16^{\mathrm{ef}}$ & $0.21^{\mathrm{df}}$ & $0.47^{\mathrm{ac}}$ & $0.26^{\mathrm{cf}}$ & $0.37^{\text {be }}$ & $0.37^{\text {be }}$ & $0.36 \mathrm{a}$ \\
\hline & 6 & $0.22^{\mathrm{df}}$ & $0.57^{\mathrm{ab}}$ & $0.21^{\mathrm{df}}$ & $0.23^{\mathrm{df}}$ & $0.33^{\mathrm{cf}}$ & $0.41^{\text {ad }}$ & $0.41^{\text {ad }}$ & $0.27^{\mathrm{ce}}$ & $0.33 \mathrm{a}$ \\
\hline \multicolumn{2}{|l|}{ Ort.(İS) } & \multicolumn{2}{|c|}{$0.34 \mathrm{a}$} & \multicolumn{2}{|c|}{$0.18 \mathrm{~b}$} & \multicolumn{2}{|c|}{$0.34 \mathrm{a}$} & \multicolumn{2}{|c|}{$0.32 \mathrm{a}$} & \\
\hline \multirow{3}{*}{$\begin{array}{c}\text { Biyomas-C } \\
\left(\mathrm{mg} 100 \mathrm{~g}^{-1} \cdot \mathrm{k} \cdot \mathrm{t}^{-1}\right)\end{array}$} & 0 & \multicolumn{2}{|c|}{$10.02^{\mathrm{h}^{* *}}$} & \multicolumn{2}{|c|}{$39.94^{\text {bc }}$} & \multicolumn{2}{|c|}{$13.91^{\text {fh }}$} & \multicolumn{2}{|c|}{$13.85^{\text {fh }}$} & $19.43 \mathrm{c}$ \\
\hline & 3 & $45.6^{\mathrm{b}}$ & $20.8^{\mathrm{eg}}$ & $12.7^{\mathrm{gh}}$ & $67.3^{\mathrm{a}}$ & $13.1^{\mathrm{gh}}$ & $17.9^{\text {fh }}$ & $17.8^{\text {fh }}$ & $22.6^{\mathrm{eg}}$ & $27.22 \mathrm{~b}$ \\
\hline & 6 & $31.2^{\mathrm{ce}}$ & $33.8^{\mathrm{cd}}$ & $19.3 \mathrm{fh}$ & $77.9^{\mathrm{a}}$ & $30.8^{\mathrm{ce}}$ & $22.1^{\mathrm{eg}}$ & $21.7^{\mathrm{eg}}$ & $24.0^{\mathrm{df}}$ & $32.62 \mathrm{a}$ \\
\hline \multicolumn{2}{|l|}{ Ort.(İS) } & \multicolumn{2}{|c|}{$25.24 \mathrm{~b}$} & \multicolumn{2}{|c|}{$42.84 \mathrm{a}$} & \multicolumn{2}{|c|}{$18.64 \mathrm{c}$} & \multicolumn{2}{|c|}{$18.98 \mathrm{c}$} & \\
\hline & 0 & \multicolumn{2}{|c|}{$4.76^{\mathrm{eh} * *}$} & \multicolumn{2}{|c|}{$5.91^{\mathrm{dg}}$} & \multicolumn{2}{|c|}{$9.72^{\mathrm{b}}$} & \multicolumn{2}{|c|}{$1.81^{1}$} & $5.55 \mathrm{c}$ \\
\hline \multirow{2}{*}{$\begin{array}{c}\text { Arıl } \\
\text { Sülfataz } \\
(\mu \mathrm{g} \text { P- N g.k.t-1) }\end{array}$} & 3 & $7.77^{\mathrm{bd}}$ & $5.28^{\mathrm{dg}}$ & $9.27^{\mathrm{b}}$ & $5.53^{\mathrm{dg}}$ & $3.09^{\mathrm{gl}}$ & $14.18^{\mathrm{a}}$ & $1.69^{1}$ & $3.62^{\mathrm{fi}}$ & $6.30 \mathrm{~b}$ \\
\hline & 6 & $9.07^{\mathrm{bc}}$ & $6.19^{\mathrm{cf}}$ & $9.81^{\mathrm{b}}$ & $7.64^{\mathrm{be}}$ & $5.38^{\mathrm{dg}}$ & $16.66^{\mathrm{a}}$ & $2.23^{\mathrm{h}}$ & $3.81^{\mathrm{fi}}$ & $7.60 \mathrm{a}$ \\
\hline \multicolumn{2}{|l|}{ Ort.(İS) } & \multicolumn{2}{|c|}{$6.31 \mathrm{c}$} & & & & & & & \\
\hline & 0 & & & & & & & & & $3.01 \mathrm{~b}$ \\
\hline (mg p-nitrofenol gr & 3 & $6.98^{\mathrm{a}}$ & $5.24^{\mathrm{bc}}$ & $4.73^{\mathrm{bd}}$ & $4.24^{\mathrm{ce}}$ & $3.15^{\mathrm{fg}}$ & $2.51^{\mathrm{gh}}$ & $3.95^{\mathrm{df}}$ & $2.74^{\mathrm{gh}}$ & $4.19 \mathrm{a}$ \\
\hline kuru toprak $\mathrm{h}^{-1}$ ) & 6 & $7.47^{\mathrm{a}}$ & $4.68^{\text {bd }}$ & $5.51^{\mathrm{b}}$ & $3.97^{\mathrm{df}}$ & $3.19^{\mathrm{eg}}$ & $2.37^{\text {gh }}$ & $4.01^{\mathrm{df}}$ & $2.71^{\text {gh }}$ & $4.24 \mathrm{a}$ \\
\hline Ort.(İS) & & & & & & & & & & \\
\hline
\end{tabular}

FZ: Fındık zurufu, BK: Biyokömür. *, **: İstatiksel olarak $\mathrm{P}<0.05$ ve $\mathrm{P}<0.01$ düzeyinde önemli, öd: İstatistiksel olarak önemli değil. Özellikler için yapılan varyans analizi sonucunda en az iki grup ortalaması arasındaki fark istatistiksel olarak önemli bulunmuştur. Aynı harfle gösterilen ortalamalar arasındaki fark, kendi grubu içerisinde önemli değildir.

aylık, biyomas-C içeriği 2 aylık, aril sülfataz enzimi ise 3 aylık inkübasyon süresinde $6 \mathrm{t} \mathrm{da}^{-1}$ uygulamasında en yüksek olurken, $\beta$-glukozidaz enzim miktarı en yüksek 1 aylık inkübasyon süresinde $6 \mathrm{t} \mathrm{da}^{-1}$ uygulamasında bulunmuştur.

\subsection{Toprak besin elementi üzerine etkisi}

Toprağa farklı dozlarda uygulanan findık zurufu ve biyokömür materyallerinin inkübasyon süresine bağlı olarak toprak besin elementi içerikleri ile ilgili veriler Çizelge 4'de verilmiştir. Toprak $\mathrm{N}$ içeriği \%0.07-0.11, P içeriği \%4.17-18.86 arasında olup 1 aylık inkübasyon süresinde, K içeriği 11.25$143.6 \mathrm{mg} \mathrm{kg}^{-1}$ arasında olup 2 aylık inkübasyon süresinde toprağa findık zurufunun $6 \mathrm{t} \mathrm{da}^{-1}$ uygulamasında en yüksek bulunmuş; ayrışmanın artmasına bağlı olarak besin içeriklerinde azalma meydana gelmiş̧ir. Toprağın mikro besin elementleri üzerine findık zurufunun uygulanması biyokömürden daha etkili etkili olmuş (Çizelge 4), ayrışmanın artmasına bağlı olarak mikro besin içerikleri azalma eğilimi göstermiştir. Toprak Mn içeriği 1.04-7.14 mg kg-1 arasında değişmiş, en yüksek 1 aylık inkübasyon süresinde $6 \mathrm{t} \mathrm{da}^{-1}$ uygulamasında bulunmuştur. Diğer yandan, toprağın Fe ve $\mathrm{Zn}$ içerikleri inkübasyon süresi ve doz, inkübasyon süresi ve organik materyal ve organik materyal ve doz etkileşimlerine bağlı olarak istatistiksel anlamda önemli farklılıklar göstermiştir $(p<0.01, p<0.05)$. Her iki besin elementi içeriği en yüksek 1 aylık inkübasyon süresinde findık zurufu uygulamasında elde edilmiş, en yüksek $\mathrm{Fe}$ içeriği toprağa 3 $\mathrm{t} \mathrm{da}^{-1}\left(11.45 \mathrm{mg} \mathrm{kg}^{-1}\right)$, Zn içeriği aynı materyalin $6 \mathrm{t} \mathrm{da}^{-1}(6.51$ $\mathrm{mg} \mathrm{kg}^{-1}$ ) uygulamasında belirlenmiştir.

\section{Tartışma ve Sonuç}

Bu çalışmada, fındık zurufu ile biyokömürün farklı dozlarda toprağa uygulanması ve inkübasyon süresine bağlı olarak toprağın fiziksel, kimyasal, biyolojik özellikleri ve besin elementi içerikleri üzerine etkisi ile ilgili sonuçlar değerlendirilmiştir.
Toprak fiziksel ve kimyasal özelliklerinde ( $\mathrm{pH}$ hariç) findık zurufu uygulamaları daha etkili olmuş, inkübasyon süresine bağlı olarak hacim ağırlığında ve organik madde içeriğinde $\% 20$, kolay alınabilir su içeriğinde \%8, agregat stabilitesinde \%27 azalma meydana gelmiştir. Buna karşılık toprağın havalanma kapasitesinde \%60, hidrolik iletkenlik \%66 ve elektriksel iletkenlik değerlerinde \%23 artış meydana gelmiştir. Uygulama dozu arttığında, hacim ağırlığı hariç, diğer özelliklerde artış görülmüştür. Yapılan çalışmalarda findık zurufunun organik madde ve besin kaynağ 1 olarak kullanılabileceği (Çalışkan ve ark. 1996), toprakların fiziksel özelliklerini iyileştirdiği (Zeytin ve Baran 2003) ifade edilmiştir. Diğer yandan, toprak $\mathrm{pH}$ 's1 üzerine biyokömür uygulamalarının genellikle toprakların pH'sını arttırdığını (Saha ve ark. 2010; Namlı ve ark. 2017; Majeed ve ark. 2018), bunun sebebi toprağın yüksek tamponlama kapasitesinin ve alkalin pH'sından kaynakladığı şeklinde açıklanmıştır (Silva ve ark. 2010). Materyallerin fiziksel ve kimyasal özellikleri (Çizelge 1) dikkate alındığında, toprak özelliklerindeki değişimlere yansıdığı oldukça açık bir şekilde görülmektedir.

Toprak biyolojik özellikleri üzerine $\beta$-glukozidaz enzim aktivitesi hariç biyokömür uygulamaları daha etkili olmuş; uygulama yapılmayan toprak koşullarına göre, toprak $\mathrm{CO}_{2}$ miktarında 5 kat, biyomas-C içeriğinde 7 kat, aril sülfataz enzim aktivitesinde 9 kat, $\beta$-glukozidaz enzim aktivitesinde ise findik zuruf uygulamaları 3 kat artış meydana getirmiştir. Biyokömürün toprağın su tutma kapasitesini, toprak pH'sını, toprak organik madde miktarını artırarak ve mikrobiyal aktiviteyi destekleyerek toprağa önemli katkılar sağladığı bildirilmiştir (Steiner ve ark. 2007; Chan ve ark. 2008; Dias ve ark. 2010). Toprağa biyokömür uygulanması mineralizasyonun artmasına bağlı olarak toprak biyolojik aktivitesinin ve bununla birlikte $\mathrm{CO}_{2}$ üretiminin arttı̆̆ (Gaunt ve ark. 2009), biyokömürün geniş $\mathrm{C} / \mathrm{N}$ oranından dolayı mikroorganizmalar tarafindan daha çok parçalanmaya maruz kalarak aril sülfataz 
Çizelge 4. Organik materyal, inkübasyon süresi ve uygulama dozlarının toprak makro-mikro besin elementi içeriklerine etkisi.

Table 4. Effects of organic material, incubation time and application doses on the macro-micro nutrient content of soil.

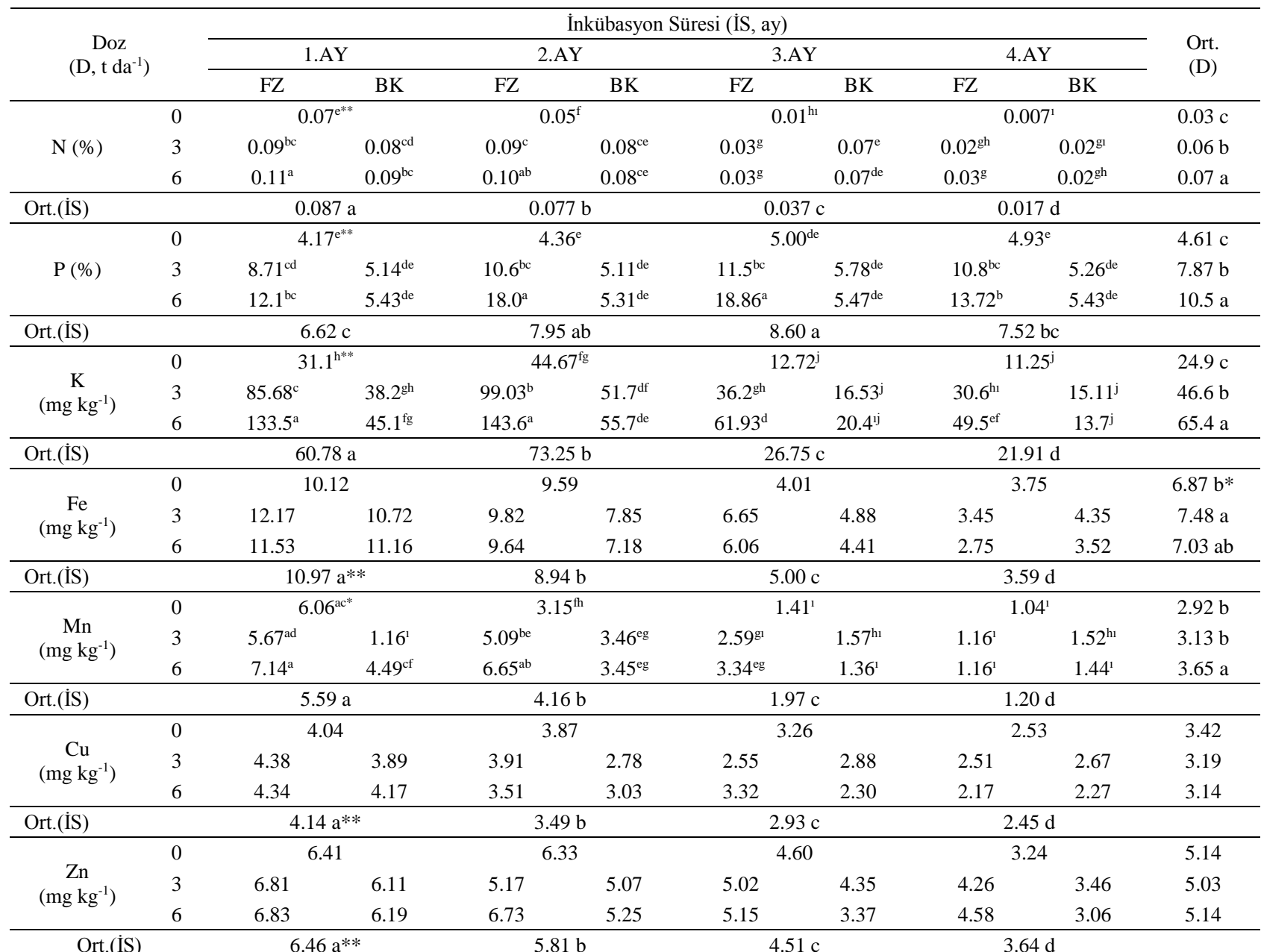

FZ: Fındık zurufu, BK: Biyokömür. *, **: İstatiksel olarak $\mathrm{P}<0.05$ ve $\mathrm{P}<0.01$ düzeyinde önemli, öd: İstatistiksel olarak önemli değil. Özellikler için yapılan varyans analizi sonucunda en az iki grup ortalaması arasındaki fark istatistiksel olarak önemli bulunmuştur. Aynı harfle gösterilen ortalamalar arasındaki fark, kendi grubu içerisinde önemli değildir.

enzimi (Ergün 2017) ve bazı enzim aktivitelerinin arttığı bildirilmiştir.

Toprağın toplam azot içeriği hem findık zurufu hem de biyokömür uygulamalarında inkübasyon süresinin uzamasına bağlı olarak azalmış; zuruf uygulamaları daha etkili olmuştur. Mikoorganizmaların azot kaynağı temin etmek için materyalleri ayrıştırması ile toprak azot içeriğinde azalmanın meydana gelmesi beklenen sonuç olmuştur. Shenbagavalli ve Mahimairaja (2012), mineral $\mathrm{N}$ değerlerinde ise inkübasyon süresinin artması ile önemli bir azalma olduğunu bildirmişlerdir. Tian ve ark. (2016), biyokömürün genellikle düşük miktarda inorganik $\mathrm{N}$ içerdiğini ifade etmişlerdir.

Toprağa findık zuruf uygulamaları biyokömüre göre alınabilir fosfor içeriğinde $\% 99$, ekstrakte edilebilir potasyum içeriğinde \%103 artış sağlamıştır. Kacar ve Katkat (1998), findık zurufunun yüksek K içeriği ile dikkat çeken bir organik atık olduğunu belirtmişlerdir. Fosfor içeriği 3 aylık (kontrole göre 4.5 kat), potasyum içeriği ise 2 aylık inkübasyon süresine (2.8 kat) kadar artış gösterirken sonra azalma eğilimine girmiştir. Toprağa her ekim döneminde biyokömür veya diğer organik materyallerin uygulanması durumunda toprağın organik madde miktarı ve buna bağlı olarak toprakta bağlı halde bulunan fosforun açığa çıkması ve bitkiler tarafından alınabilir forma geçmesinin mümkün olabileceğini bildirilmiştir (Namlı ve ark. 2017).

Toprağın mikro besin element içerikleri inkübasyon süresine bağlı olarak azalmış, diğer özelliklerde olduğu gibi findık zuruf uygulanan toprakların ekstrakte edilebilir demir, mangan, bakır ve çinko içerikleri daha yüksek çıkmıştır. Karaca (2016), findık zuruf kompostu uygulamaları toprağın toplam $\mathrm{N}$ içeriğinin inkübasyon süresine bağlı olarak azaldığı, toprağın $P$ ve Fe içeriklerini artırdığ 1 ancak, inkübasyonun 6. ayından sonra azaldığını, Mn içeriklerinin inkübasyon süresiye birlikte toprakta 9. aya kadar arttığını bildirmiştir. Kacar ve Katkat (2009), toprağa organik materyallerin uygulanması durumunda kileyt oluşturucu bileşiklerin oluştuğu ve bu Fe ve Mn'1 bitkilere yarayışlı hale getirdiğini belirtmişlerdir.

Tüm veriler değerlendirildiğinde, toprak düzenleyicisi olarak kullanılan atıklar incelenen özellikleri olumlu yönde etkilemiştir. Fındık zurufu toprak fiziko-kimyasal özellikleri (pH hariç) ile besin elementi kapsamı üzerine daha fazla etkili olurken, toprak biyolojik özelliklerinde ( $\beta$-glukozidaz enzim aktivitesi hariç) biyokömürün etkisi öne çıkmıştır. Diğer yandan, materyallerin dozu arttıkça etkileri artmış, ancak 3 
$\mathrm{t} \mathrm{da}^{-1}$ uygulama istatistiki olarak yeterli bulunmuştur. İnkübasyon süresinin etkisi, incelenen özelliklerde değişkenlik göstermiştir. Sonuç olarak, her iki materyalin toprak düzenleyicisi olarak kullanılabileceği, findık zurufunun kısa dönemde daha etkili olduğu, biyokömürün ise uzun dönemde etkisinin görülebileceği düşünülmektedir.

\section{Kaynaklar}

Anderson JPE (1982) Soil respiration. In: Page AL, Miller RH, Keeney DR (Eds), Methods of Soil Analysis, part 2, 2nd Edition, ASA and SSSA, Madison, pp. 837-871.

Alaoui A, Lipiec J, Gerke HH (2011) A review of the changes in the soil pore system due to soil deformation: A hydrodynamic perspective. Soil Till Res. 115-116: 1-15.

Aygün S (2015) Findık zurufu kompostunun toprak kalitesi üzerine etkisi. Yüksek Lisans Tezi, Ordu Üniversitesi Fen Bilimleri Enstitüsü, Ordu.

Bender Özenç D (2005) Usage of hazelnut husk compost as growing medium. Acta Hort. 686: 309-319.

Bender Özenç D, Özenç N (2008) Short-term effects of hazelnut husk compost and organic amendment applications on clay loam soil. Compost Science \& Utilization 16(3): 192-199.

Birol Y, Bender Özenç D (2011) Fındık zuruf kompostunun sıkıştırılmış killi tınlı bir toprağın fiziksel özellikleri üzerine etkisi. Prof. Dr. Nuri Munsuz Ulusal Toprak ve Su Sempozyumu, Ankara, s. 77-85.

Blake G R, Hartge KH (1986) Bulk Density, Particle Density. In: Methods of Soil Analysis. Part I, ASA-SSSA, Madison, WI, pp. 363-382.

Bouyoucos GD (1951) A recalibration of the hydrometer method for making mechanical analysis of the soil. Agronomy Journal (9): 434-438.

Chan KY, Van Zwieten L, Meszaros I, Downie A, Joseph S (2008) Agronomic values of green waste biochar as a soil amendment. Soil Research 45(8): 629-634.

Cheng H, Xu W, Liu J, Zhao Q, He Y, Chen G (2007) Application of composted sewage sludge (CSS) as a soil amendment for turf grass growth. Ecol Eng. 29: 96-104.

Çalışkan N, Koç N, Kaya A, Şenses T (1996) Fındık Zurufundan Kompost Elde Edilmesi. Fındık Araştırma Enstitüsü Müdürlüğü Sonuç Raporu, Giresun, s. 41.

De Boodt M, Verdonck O, Cappaert I (1973) Method for measuring the water release curve of organic substrates. Proc. Sym. Artificial Media in Horticulture, pp. 2054-2062.

De Lucia B, Cristiano G (2015) Composted amendment affects soil quality and hedges performance in the Mediterranean urban landscape. Compost Sci Util. 23: 48-57.

Demiralay İ (1993) Toprak Fiziksel Analizleri. Atatürk Üniversitesi Ziraat Fakültesi Yayınları No.143, Erzurum.

Dias BO, Silva CA, Higashikawa F.S, Roig A, Sanchez-Monedero MA (2010) Use of biochar as bulking agent for the composting of poultry manure; effect on organic matter degradation and humification. Bioresource Technology 101: 1239-1246.

Eivazi F, Tabatabai MA (1988) Glucosidases and galactosidases in soils. Soil Biology and Biochemistry 20(5): 601-606.

Ergün YA (2017) Biyokömür ve ahır gübresi uygulamalarının topraktaki bazı enzim aktivitelerine, $\mathrm{CO}_{2}$ üretimine, besin elementi içeriğine ve domates bitkisinin gelişimine etkisi. Yüksek Lisans Tezi, Ordu Üniversitesi Fen Bilimleri Enstitüsü, Ordu.

Ferreras L, Gomez E, Toresani S, Firpo I, Rotondo R (2006) Effect of organic amendments on some physical, chemical and biological properties in a horticultural soil. Bioresour Technol. 97: 635-640.
Gaunt J, Cowie A (2009) Biochar, greenhouse gas accounting and emissions trading. Biochar for environmental management: Science and technology pp. 317-340.

González M, Gomez E, Comese R, Quesada M, Conti M (2010) Influence of organic amendments on soil quality potential indicators in an urban horticultural system. Bioresour Technol. 101: 8897-8901.

Grandy AS, Porter GA, Erich MS (2002) Organic amendment and rotation crop effects on the recovery of soil organic matter and aggregation in potato cropping systems. Soil Science Society of America Journal 66: 1311-1319.

Gülser C, Kızılkaya R, Aşkın T, Ekberli I (2015) Changes in soil quality by compost and hazelnut husk applications in a hazelnut orchard. Compost Science Utilization 23(3): 135-141.

Isermeyer $H$ (1952) Eine einfache methode zur bestimmung der karbonate im boden, Zeitschrift für Planzenernährung, Düngung Bodenkunde 561(3): 26-38.

İslam E (2016) Fındık zurufu kompostunun toprak mekaniksel özellikleri üzerine etkisi. Yüksek Lisans Tezi, Ordu Üniversitesi Fen Bilimleri Enstitüsü, Ordu.

Kacar B (2009) Toprak Analizleri. Nobel Yayın No:1387. Ankara.

Kacar B, Katkat AV (1998). Bitki Besleme. Uludağ Üniversitesi Güçlendirme Vakfı Yayın No:127, VİPAŞ Yayınları: 3, Bursa, s. 595.

Kacar B, Katkat VA (2009) Bitki Besleme. Nobel Yayın No:849, Fen Bilimleri: 30, Nobel Bilim ve Araştırma Merkezi Yayın No: 49, Bursa, s. 645.

Kacar B, Kütük C (2010) Gübre Analizleri. Nobel Yayın No: 1497, Ankara.

Karaca E (2016) Findık zurufu kompostunun toprakların ve findık bitkisi yapraklarının besin maddesi içerikleri üzerine etkisi. Yüksek lisans tezi, Ordu Üniversitesi Fen Bilimleri Enstitüsü, Ordu.

Khai NM, Ha PQ, Vinh NC, Gustafsson JP, Öborn I (2008) Effects of biosolids application on soil chemical properties in peri-urban agricultural systems. VNU J Sci Earth Sci. 24: 202-212.

Kızılkaya R, Sahin N, Tatar D, Veyisoğlu A, Askın T, Sushkova SN, Minkina TM, 2015. Isolation and identification of bacterial strains from decomposing hazelnut husk. Compost Science \& Utilization 23(3): 173-184.

Lal R (2009) Soils and food sufficiency. A review. Agronomy for Sustainable Development 29: 113-133.

Lehmann J, Rondon M (2006) Biochar soil management on highly weathered soils in the humid tropics. In: Uphoff N. et al. (Eds.), Biological Approaches to Sustainable Soil Systems. Florida: CRC Press, Taylor and Francis Group. pp. 517-530.

Lehmann J (2007) A handful of carbon. Nature 447(7141): 143-144.

Majeed AJ, Dikici H, Demir ÖF (2018) Effect of biochar and nitrogen applications on growth of corn (Zea mays L.) plants. Turkish Journal of Agriculture-Food Science and Technology 6(3): 346351.

Namlı A, Akça MO, Akça H (2017) Tarımsal atıklardan elde edilen biyokömürün buğday bitkisinin gelişimi ve bazı toprak özellikleri üzerine etkileri. Toprak Bilimi ve Bitki Besleme Dergisi 5(1): 3947.

Özenç N (2004) Fındık zurufu ve diğer organik materyallerin fındık tarımı yapılan toprakların özellikleri ve ürün kalitesi üzerine etkileri. Doktora Tezi, Ankara Üniversitesi Fen Bilimleri Enstitüsü, Ankara.

Özenç N, Çalışkan N (2001) Effects of husk compost on hazelnut yield and quality. Acta Hortic. 556: 559-566.

Rinaldi S, De Lucia B, Salvati L, Rea E (2014) Understanding complexity in the response of ornamental rosemary to different substrates: A multivariate analysis. Sci Hortic. 176: 218-224. 
Saha S, Gopinath KA, Mina BL, Kundu S, Bhattacharaya R, Gupta S (2010) Expression of soil chemical and biological behavior on nutritional quality of aromatic rice as influenced by organic and mineral fertilization. Commun. Soil Sci Plant Analysis 41(15): $1816-1831$

Silva MAG, Roque SAT, Muniz AS, Marchetti ME, Matta JDV, Pelisson N (2010) Efficiency of organic compost from AgriIndustrial wastes as fertilizer for corn and wheat. Commun. Soil Sci. Plant Analysis 41(21): 2517-2531.

Steiner C, Teixeira WG, Lehmann J, Nehls T, de Macêdo JLV, Blum W E, Zech W (2007) Long term effects of manure, charcoal and mineral fertilization on crop production and fertility on a highly weathered Central Amazonian upland soil. Plant and soil 291(1-2): 275-290.

Stellacci AM, Cristiano G, Rubino P, De Lucia B, Cazzato E (2013) Nitrogen uptake, nitrogen partitioning and $\mathrm{N}$-use efficiency of container-grown Holm oak (Quercus ilex L.) under different nitrogen levels and fertilizer sources. Int J Food Agric Environ. 11: 132-137.

Shenbagavalli C, Mahimairaja S (2012) Characterization and effect of biochar on nitrogen and carbon diynamics in soil. Int. J. Adv. Bio. Res. 2(2): 249-255.
Sönmez N (1960) Hidrolik Kondaktivite Ve Burgu Deliği Metodu İle Taban Suyu Seviyesinin Altında Hidrolik Kondaktivitenin Ölçülmesi. A.Ü. Ziraat Fakültesi Yayınları, No: 164, Ankara.

Tarakçıŏlu C, Özenç DB, Yılmaz FI, Kulaç S, Aygün, S (2019) Fındık kabuğundan üretilen biyokömürün toprağın besin maddesi kapsamı üzerine etkisi. Anadolu Tarım Bilimleri Dergisi 34(1): 107-117.

Tabatabai MA, Bremner JM (1970) Arylsulfatase activity of soils. Soil Science Society of America Journal 34: 225-229.

Tian J, Wang J, Dippold M, Gao Y, Blagodatskaya E, Kuzyakov Y (2016) Biochar affects soil organic matter cycling and microbial functions but does not alter microbial community structure in a paddy soil. Science of the Total Environment 556: 89-97.

Warnock DD, Lehmann J, Kuyper TW, Rillig MC (2007) Mycorrhizal responses to biochar in soil-concepts and mechanisms. Plant Soil 300: 9-20.

Zare M, Afyuni M, Abbaspour KC (2010) Effects of biosolids application on temporal variations in soil physical and unsaturated hydraulic properties. J. Residuals Sci. Technol. 7: 227-235.

Zeytin S, Baran A (2003) Influences of composted hazelnut husk on some physical properties of soils. Bioresource Technology 88(3): 241-244. 